\title{
Steroid Cell Tumor of Ovary Diagnosed After Delivery; Case Report
}

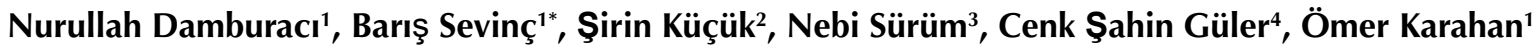 \\ 'Department of General Surgery, Medical School, Uşak University, Uşak, Turkey \\ ${ }^{2}$ Department of Pathology, Medical School, Uşak University, Uşak, Turkey \\ ${ }^{3}$ Emergency Department, Medical School, Uşak University, Uşak, Turkey \\ ${ }^{4}$ Department of Anesthesiology, Uşak University, Uşak, Turkey
}

*Corresponding Author: Barış Sevinç, M.D., Assistant Professor, Department of General Surgery, Medical School, Uşak University, Uşak, Turkey. Tel: +90-5054880511, Email: drbarissevinc@gmail.com

Received November 24, 2017; Accepted December 19, 2017; Online Published January 27, 2018

\begin{abstract}
Introduction: Steroid cell tumors (SCTs) constitute less than $0.1 \%$ of all ovarian tumors. They are divided into 3 categories according to cell of origin: Stromal Luteoma arising from stromal cells of the ovary, Leydig cell tumor arising from Leydig cells, and SCT not otherwise specified (NOS) when the origin of the tumor is not defined.

Case Presentation: Herein is presented a case of SCT diagnosed one month after a caesarian section delivery of a female fetus with ambiguous genitalia. The patient was admitted to the emergency department with the findings of acute abdomen, and surgery was performed under emergency conditions. The patient had virilization and hoarsening of the voice before surgery. Intraoperatively, a $21-\mathrm{cm}$ ovarian mass was detected and resected with unilateral salpingo-oophorectomy. Conclusion: A histopathological examination of the tumor showed a tumor with cystic degeneration, necrosis, hemorrhage, and tumoral embolism. The pathological examination revealed ovarian SCT. Virilization was resolved immediately after the surgery. In women with virilization who give birth to a fetus with ambiguous genitalia, SCTs should be kept in mind.

Keywords: Steroid Cell Tumor, Virilisation, Ambigous Genitalia
\end{abstract}

\section{Introduction}

Steroid cell tumors (SCT) constitute less than $0.1 \%$ of all ovarian tumors. ${ }^{1,2}$ SCT are divided into 3 categories according to the cell of origin: Stromal luteoma arising from stromal cells of ovary, Leydig cell tumor arising from Leydig cells, and SCT not otherwise specified (NOS) when the origin of the tumor is not defined. ${ }^{2,3}$ NOS constitutes $60 \%$ of all SCT. The majority (>90\%) of NOS are unilateral. ${ }^{4}$ In this report, a case with NOS who presented with acute abdomen one month after delivery is presented.

\section{Case Presentation}

A 25-year-old female patient was admitted to the Emergency Department with complaints of acute abdominal pain. She had given birth to a female baby one month earlier by caesarean section. The infant had ambiguous genitalia and was under examination in the Pediatric Endocrinology Department. Physical examination of the patient upon admittance revealed signs of virilization (hirsutism, deepening of the voice, temporal baldness, clitoral enlargement) and rebound tenderness at all quadrants of the abdomen. Laboratory studies showed an increased leukocyte count (12300) with increased C reactive protein levels $(60 \mathrm{mg} / \mathrm{L})$. Biochemical tests were in the normal range. Abdominal ultrasonography and computed tomography showed a huge intraabdominal mass with an unidentified origin (Figure 1). Due to findings of acute abdomen and history of recent surgery, the patient was taken for an emergency laparotomy. At the intraoperative examination, a tumor of $21 \mathrm{~cm}$ originating from the left ovary was detected. The tumor was resected with unilateral salpingo-oophorectomy (Figure 2). The patient was discharged from the hospital with no postoperative complications on the third postoperative day. At discharge, only oral paracetamol $500 \mathrm{mg}$ twice daily was prescribed; no other medication was administered. At the follow-up visit, all findings of virilization were resolved. Histopathological examination of the tumor showed a tumor with cystic degeneration, necrosis, hemorrhage, and tumoral embolism. The tumor showed grade 2 nuclear atypia, 1-2 mitotic figures in ten high-power fields. Immunohistochemistry showed positivity for calretinin and negative for inhibin (Figure 3). All findings were in accordance with malignant ovarian SCT.

Copyright $($ C 2018 The Author(s). This is an open-access article distributed under the terms of the Creative Commons Attribution License (http:// creativecommons.org/licenses/by/4.0), which permits unrestricted use, distribution, and reproduction in any medium, provided the original work is properly cited. 


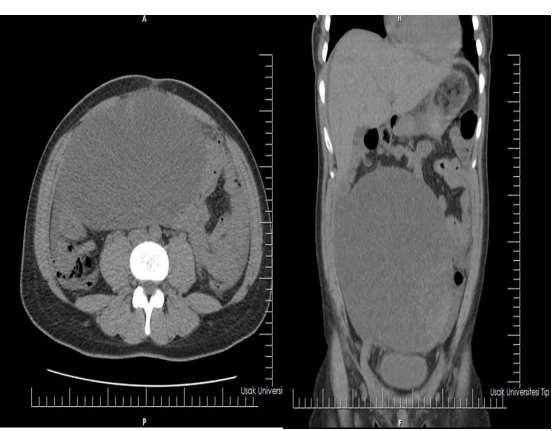

Figure 1. Axial and Sagittal Computed Tomography Showing Huge Intraabdominal Mass With Unidentified Origin.

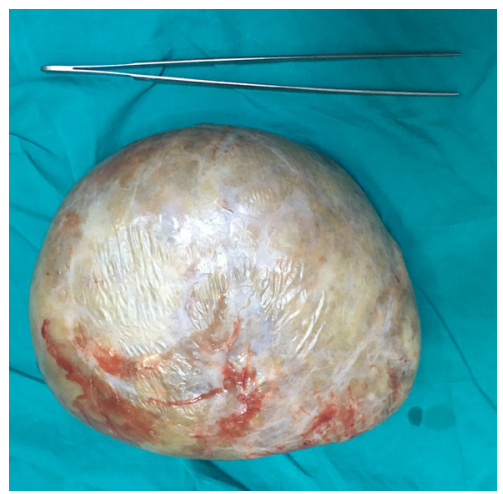

Figure 2. Resected Tumoral Mass.

\section{Discussion}

SCT accounts for less than $0.1 \%$ of all ovarian neoplasia, and $25 \%-40 \%$ of SCT are malignant. ${ }^{4}$ For NOS tumors, the origin of the cell line is not defined, and they are not categorized as either stromal luteoma or Leydig cell tumors. ${ }^{2,5}$ According to Hayes and Scully, malignant characteristics include two or more mitotic figures per $10 \mathrm{HPF}$, tumor necrosis, tumor diameter $>7 \mathrm{~cm}$, tumor hemorrhage, and grade 2-3 nuclear atypia. ${ }^{2}$ With a diameter of $21 \mathrm{~cm}$, necrosis, hemorrhage, and grade 2 nuclear atypia, the present case is accepted as malignant SCT.

More than $90 \%$ of SCT are unilateral. ${ }^{4}$ Although, most of these tumors are benign, they may behave clinically malignant with intraperitoneal metastasis., ${ }^{4,6,7}$ Most SCT secrete hormones. Moreover, in most cases, androstenedione and testosterone levels are increased..$^{8-11}$ Serum total testosterone may be used as a marker in the follow-up of the patient, because increased testosterone levels most commonly indicate virilization. ${ }^{12}$ However, in a small number of cases, especially with small tumors, testosterone levels are not increased and those cases are diagnosed as SCT postoperatively. ${ }^{13}$ In the present case, virilization began with pregnancy; however, the tumor was diagnosed during neither the pregnancy nor the caesarean delivery, and the virilization was resolved after surgery.

To the best of the authors' knowledge, only three cases of SCT detected during pregnancy is reported in the literature. ${ }^{14-16}$ The current case is the fourth one. The first case gave birth to a fully healthy male infant. ${ }^{14}$ The

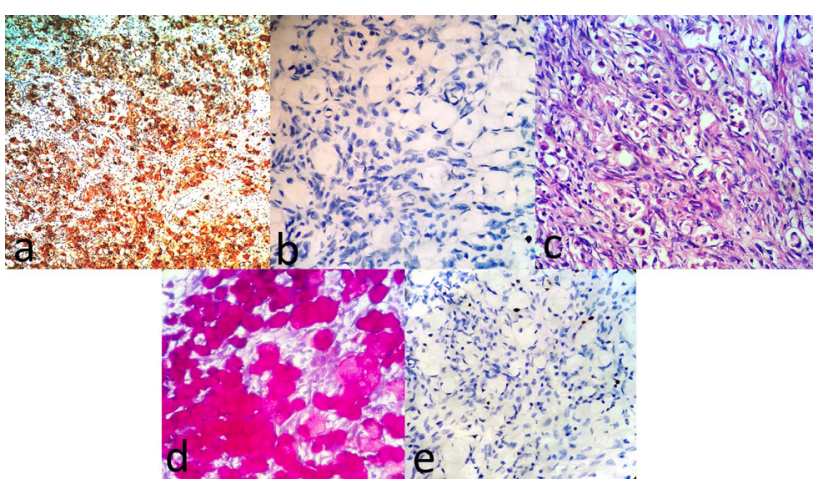

Figure 3. (a) Tumoral Cells With Sharp Borders, Polygonal-Oval Shaped, Eosinophilic, Clear and Vacuolized Cytoplasm and Nuclei With Centrally Localized Nucleoli (H\&E, 40x). (b) Lymphatic Tumoral Embolus in Highly Vascularized Stroma (H\&E, x40). (c) nuclear and cytoplasmic calretinin positivity. (d) Inhibin negativity.

second case, as in the current one, the baby had ambiguous genitalia. ${ }^{16}$ Most probably, maternal androgens caused the disorder in the baby. Safe salpingo-oophorectomy could be performed in the first trimester to protect the baby. However, in the present case the tumor was not detected during pregnancy, nor during delivery.

Pathological examination is very important in the diagnosis of SCT. Macroscopically, the tumor is seen as a solid, well circumference tumoral mass with occasional hemorrhage and cystic formations. ${ }^{16-19}$ In a cytological examination, polyglonal or round cells with distinctive borders and central and prominent nucleoli are seen. ${ }^{20}$ SCTs are differentiated from Leydig cell tumors by the absence of Reinke's crystals. Immunohistochemistry is also very important in making a diagnosis. SCTs are usually calretinin, inhibin and vimentin positive. ${ }^{21}$ However, in some reports, inhibin positivity may range from $5 \%-90 \% .{ }^{22}$ Moreover, cytokeratin, EMA, CD 99, and S 100 may be positive. However, CgA, LeuM1, alpha fetoprotein, and carcinoembryonic antigen are reported as negative. In the present case, calretinin, vimentin, and EMA were found to be positive. Although inhibin was negative in this case, the vast variation in inhibin positivity may be accepted as an explanation. Moreover, CEA positivity was never reported in the literature. In the current case, CEA was also found to be positive.

Primary treatment of SCT is unilateral salpingooophorectomy and regular staging with lymph node dissection, omentectomy, and appendectomy in young cases with unilateral tumor and preservation of fertility. ${ }^{23}$ In postmenopausal patients or bilateral tumors, hysterectomy with bilateral salpingo-oophorectomy can be performed. ${ }^{6}$ For metastatic cases, debulking surgery and chemotherapy or radiotherapy are recommended. ${ }^{6,24}$

\section{Conclusion}

This report represents a case with SCT during pregnancy which caused ambiguous genitalia in the fetus. In case of maternal virilization and fetal pseudohermaphrodism and ovarian SCT should be kept in mind. 


\section{Authors' Contributions}

All authors contributed equally to this research.

\section{Conflict of Interest Disclosures}

The authors declare that there is no conflict of interest.

\section{Ethical Approval}

For ethical approval of this study, informed consent was obtained from the patient.

\section{References}

1. Hartman LC, Young RH, Evans MP, Podratz KC. Ovarian sex cord-stromal tumors. In: WJ Hoskins, CA Perez, RC Young, eds. Principles and Practice of Gynecologic Oncology. 2nd ed. Philadelphia, Lippincott-Raven; 1997:1015-1019.

2. Hayes MC, Scully RE. Ovarian steroid cell tumors (not otherwise specified). A clinicopathological analysis of 63 cases. Am J Surg Pathol. 1987;11(11):835-845. doi:10.1097/00000478198711000-00002.

3. Kim YT, Kim SW, Yoon BS, et al. An ovarian steroid cell tumor causing virilization and massive ascites. Yonsei Med J. 2007;48(1):142-146. doi:10.3349/ymj.2007.48.1.142.

4. Outwater EK, Wagner BJ, Mannion C, McLarney JK, Kim B. Sex cord-stromal and steroid cell tumors of the ovary. Radiographics. 1998;18(6):1523-1546. doi:10.1148/radiographics.18.6.9821198.

5. Amneus MW, Natarajan S. Pathologic quiz case: a rare tumor of the ovary. Arch Pathol Lab Med. 2003;127(7):890-892. doi:10.1043/1543-2165(2003)127<890:pqcart>2.0.co;2.

6. Li K, Zhu F, Xiong J, Liu F. A rare occurrence of a malignant ovarian steroid cell tumor not otherwise specified: A case report and literature review. Oncol Lett. 2014;8(2):770-774. doi:10.3892/ol.2014.2233.

7. Mehdi G, Ansari HA, Sherwani RK, Rahman K, Akhtar N. Ovarian steroid cell tumour: correlation of histopathology with clinicopathologic features. Patholog Res Int. 2011;2011:987895. doi:10.4061/2011/987895.

8. Cserepes E, Szucs N, Patkos P, et al. Ovarian steroid cell tumor and a contralateral ovarian thecoma in a postmenopausal woman with severe hyperandrogenism. Gynecol Endocrinol. 2002;16(3):213-216. doi:10.1080/gye.16.3.213.216.

9. Udhreja PR, Banerji A, Desai DP, Vaishnani JB. Androgensecreting steroid cell tumor of the ovary. Indian J Pathol Microbiol. 2014;57(1):94-97. doi:10.4103/0377-4929.130911.

10. Chung DH, Lee SH, Lee KB. A case of ovarian steroid cell tumor, not otherwise specified, treated with surgery and gonadotropin releasing hormone agonist. J Menopausal Med. 2014;20(1):3942.doi:10.6118/jmm.2014.20.1.39.

11. Haroon S, Idrees R, Fatima S, Memon A, Kayani N. Ovarian steroid cell tumor, not otherwise specified: a clinicopathological and immunohistochemical experience of 12 cases. J Obstet Gynaecol Res. 2015;41(3):424-431. doi:10.1111/jog.12537.
12. Vulink AJ, Vermes I, Kuijper P, ten Cate LN, Schutter EM. Steroid cell tumour not otherwise specified during pregnancy: a case report and diagnostic work-up for virilisation in a pregnant patient. Eur J Obstet Gynecol Reprod Biol. 2004;112(2):221227. doi:10.1016/j.ejogrb.2003.06.001.

13. Wang $\mathrm{PH}$, Chao HT, Lee RC, et al. Steroid cell tumors of the ovary: clinical, ultrasonic, and MRI diagnosis--a case report. Eur J Radiol. 1998;26(3):269-273. doi:10.1016/S0720048X(96)01133-3.

14. Oz M, Ozgu E, Turker M, Erkaya S, Gungor T. Steroid cell tumor of the ovary in a pregnant woman whose androgenic symptoms were masked by pregnancy. Arch Gynecol Obstet. 2014;290(1):131-134. doi:10.1007/s00404-014-3165-0.

15. Parikh B, Williams S, Heller DS. Ovarian steroid-cell tumor in pregnancy - a rare occurrence: report of a case and review of the literature. J Gynecol Surg. 2016;32(6):351-353. doi:10.1089/gyn.2016.0044.

16. Hasegawa $\mathrm{K}$, Minami $\mathrm{Y}$, Inuzuka $\mathrm{H}$, et al. Female pseudohermaphroditism associated with maternal steroid cell tumor, not otherwise specified of the ovary: a case report and literature review. Clin Exp Obstet Gynecol. 2013;40(4):591595.

17. Jiang W, Tao X, Fang F, Zhang S, Xu C. Benign and malignant ovarian steroid cell tumors, not otherwise specified: case studies, comparison, and review of the literature. J Ovarian Res. 2013;6:53. doi:10.1186/1757-2215-6-53.

18. Bhagat R, Bodal VK, Gupta N, Garg P. Steroid Cell Tumour of Ovary - A Rare Case Report. J Clin Diagn Res. 2016;10(9):Ed06 ed07. doi:10.7860/jcdr/2016/15767.8556.

19. Tasdemir N, Celik C, Abali R, Aksu E, Oznur M, Yilmaz M. A rare cause of virilization; Ovarian steroid cell tumor, not otherwise specified (NOS). J Turk Ger Gynecol Assoc. 2012;13(4):275277. doi:10.5152/jtgga.2012.45.

20. Yuan M, Qiu M, Zhu M. Symptomatic Cushing syndrome and hyperandrogenemia revealing steroid cell ovarian neoplasm with late intra-abdominal metastasis. BMC Endocr Disord. 2014;14:12. doi:10.1186/1472-6823-14-12.

21. Jones MW, Harri R, Dabbs DJ, Carter GJ. Immunohistochemical profile of steroid cell tumor of the ovary: a study of 14 cases and a review of the literature. Int J Gynecol Pathol. 2010;29(4):315320.doi:10.1097/PGP.0b013e3181c7c977.

22. Deavers MT, Malpica A, Ordonez NG, Silva EG. Ovarian steroid cell tumors: an immunohistochemical study including a comparison of calretinin with inhibin. Int J Gynecol Pathol. 2003;22(2):162-167. doi:10.1097/00004347-20030400000008.

23. Boyraz G, Selcuk I, Yusifli Z, Usubutun A, Gunalp S. Steroid cell tumor of the ovary in an adolescent: a rare case report. Case Rep Med. 2013;2013:527698. doi:10.1155/2013/527698.

24. Sood N, Desai K, Chindris AM, Lewis J, Dinh TA. Symptomatic Ovarian Steroid Cell Tumor not Otherwise Specified in a Post-Menopausal Woman. Rare Tumors. 2016;8(2):6200. doi:10.4081/rt.2016.6200. 